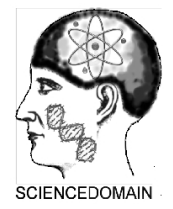

\title{
Therapeutic Effect of Curcumin Supplementation in the Modulation of NF-KB Responsive Genes in a Collagen-induced Arthritis Rat Model
}

\author{
Shanmugam Somasundaram ${ }^{1}$, Srikumar Chakravarthi ${ }^{{ }^{*}}$, \\ Ammu Radhakrishnan ${ }^{3}$, Premdass Ramdas ${ }^{3}$, \\ Nagaraja Haleagrahara ${ }^{4}$ and Mangala Kumari ${ }^{3}$ \\ ${ }^{1}$ Faculty of Medicine, Australian National University, Canberra, Australia. \\ ${ }^{2}$ Department of Pathology, Faculty of Medicine, Perdana University Graduate School of \\ Medicine, Selangor, Malaysia. \\ ${ }^{3}$ Departments of Pathology and Human Biology, International Medical University, Kuala \\ Lumpur, Malaysia. \\ ${ }^{4}$ Faculty of Medicine, Health and Molecular Science, James Cook University, Townsville, \\ Australia.
}

Authors' contributions

Author SC was the principal investigator, analysed the histopathology and immunohistochemistry work. Author AR designed the study and the protocol, directed the research scholar. Author SS performed all the lab work, review of literature, references and wrote the first draft of the manuscript. Author NH managed the statistical analyses of the study. Authors PR and MK assisted in the lab work for Elisa and the animal maintenance and sacrifice procedure. All authors read and approved the final manuscript.

Oriqinal Research Article
Received $18^{\text {th }}$ October 2013 Accepted $20^{\text {th }}$ February 2014 Published $10^{\text {th }}$ March 2014

\section{ABSTRACT}

Aims: To assess the therapeutic effect of curcumin supplementation in modulating the expression of NF-KB in the joints of collagen-induced arthritis (CIA) rats.

Place and Duration of Study: Department of Postgraduate Studies and Research, International Medical University, between July 2011 and May 2012.

Methodology: Arthritis was induced in each group of Dark Agouti (DA) rats, by 
intradermal injection with collagen emulsified in complete Freund's adjuvant. Treatment groups which were induced with CIA were treated with: $500 \mathrm{mg} / \mathrm{kg}$ curcumin; $1000 \mathrm{mg} / \mathrm{kg}$ curcumin; $2000 \mathrm{mg} / \mathrm{kg}$ curcumin; $25 \mathrm{mg} / \mathrm{kg}$ aspirin. Combination treatment groups which were induced with ClA were treated with: $500 \mathrm{mg} / \mathrm{kg}$ curcumin and $25 \mathrm{mg} / \mathrm{kg}$ aspirin; 1000 $\mathrm{mg} / \mathrm{kg}$ curcumin and $25 \mathrm{mg} / \mathrm{kg}$ aspirin; $2000 \mathrm{mg} / \mathrm{kg}$ curcumin and $25 \mathrm{mg} / \mathrm{kg}$ aspirin from day 25 to 38. Efficacy was assessed based on ability to reduce paw oedema, histopathological changes, NF-KB expression, serum tumour necrosis factor alpha (TNF$\alpha$ ), interleukin 1-beta (IL-1 $\beta$ ) and gluthathione peroxidase (GPx) levels.

Results: Based on histopathological study, immunohistochemical scoring of NF-kB and ELISA analysis of TNF- $\alpha$, IL- $1 \beta$ and GPx levels, our study found that curcumin given after arthritis in high doses, shows effects of healing and this results were comparable to positive control group, which is the arthritic group treated with $25 \mathrm{mg} / \mathrm{kg}$ aspirin. Curcumin given in combination with aspirin, showed better reduction in pathology in arthritic group compared to positive control group, especially with higher doses of curcumin.

Conclusion: Curcumin was effective in reducing inflammatory changes seen in CIA joints which were proved through histopathological, immunohistochemical and biochemical analysis, however only at high doses.

Keywords: Curcumin; nuclear factor kappa B; collagen-induced arthritis; rheumatoid arthritis; gluthathione peroxidase; tumour necrosis factor alpha; interleukin 1-beta.

\section{INTRODUCTION}

Curcumin, also known as diferuloylmethane, is a natural compound and principal curcuminoid of turmeric has been used in Indian Ayurvedic medicine for various diseases and ailments, besides culinary and textile use due to its characteristic yellow colour [1,2]. There are overwhelming evidences on various properties of curcumin. The widely studied properties are anti-inflammatory, antioxidant and anticancer [2]. Thus, it has a potential against various inflammatory diseases, malignancy, allergies and other chronic illnesses. Curcumin has been extensively studied for its anti-inflammatory properties, and discovery of various pathways on how curcumin exert this effect have been found [3-6]. One of them is through the inhibition of nuclear factor kappa B (NF-kB), transcription factor involved in inflammation [7].

Nuclear factor kappa B (NF-KB) transcription factors are a family of structurally related eukaryotic transcription factors that promote the expression of well over 150 genes involved in a variety of cellular process [8]. Numerous studies have reported that the NF-kB proteins have diverse roles in B-cell development, proliferation, and effector functions, as well as proliferation of T-cell [9]. Synovial tissue, both human and several animal models of rheumatoid arthritis (RA0 have been shown to ubiquitously express NF-KB $[10,11]$. One such animal model is collagen-induced arthritis (CIA).

Rheumatoid arthritis is one of the oldest known afflictions to mankind [12] and also the commonest form of chronic polyarthritis [13]. It is characterised as chronic, systemic inflammatory disorder that mainly attacks the joints, in addition to various other tissues and organs such as skin, blood vessels, heart, lungs and muscles [14]. A systematic review conducted in 2005 based on the 1987 American College of Rheumatology Criteria revealed that estimated prevalence of RA worldwide is between $0.2 \%$ and $1.2 \%$ [15]. Populationbased studies on epidemiology of RA are limited especially in the developing countries. 
However, available evidence suggests that incidence of RA is skewing towards elderly age of onset and the incidence in women is on the rise. The mortality rate for the elderly population with RA is on the rise likely due to multi systemic manidestation of RA [16]. To date, the exact cause of RA has not been demonstrated. Studies have shown that the aetiology is multifactorial, which takes genetic factors [17] and environmental factors [18,19].

There is no cure for RA. Current treatment options focus improving the quality of life of a RA patient. Disease modifying anti-rheumatic drugs (DMARDs), biologics and non-steroidal antiinflammatory drugs (NSAIDs) are the frequently used therapeutics for the treatment of RA [20]. In spite of variety of treatment options available, a need for a safer and more efficient drug is still there. This is mainly due to the financial burden and side effects associated with current therapeutic option. Hence, the spotlight is being diverted toward natural compounds, which aid the boost of the "nutraceutical revolution".

NF-KB plays a substantial role in rheumatoid arthritis and has been under the spotlight as a new potential therapeutic target for the treatment of RA [11,21]. Thus, we aim to assess the therapeutic effect of curcumin supplementation in modulating the expression of NF-kB in the joints of $\mathrm{ClA}$ rats.

\section{MATERIALS AND METHODS}

\subsection{Experimental Animals}

Female, Dark Agouti rats, were obtained at 6-10 weeks old from Institute of Medical Research (IMR), Malaysia and were acclimatized and maintained in Laboratory Animal House, International Medical University (IMU) under specific pathogen-free conditions. Each treatment group consisted of 6 rats.

\subsection{Development of CIA}

Collagen from chicken sternal cartilage Type II, Complete Freund's Adjuvant (CFA), Acetic Acid $99.8 \%$ was purchased from Sigma Aldrich, USA. Collagen induced arthritis was developed in the rats according to the protocol described by Brand et al. [22]. The type II collagen was reconstituted in $5 \mathrm{ml}$ of $0.1 \mathrm{M}$ cold acetic acid and was added to the Complete Freund's Adjuvant (CFA) at a ratio of 1:1. The mixture was later homogenised for approximately 20 minutes at $4^{\circ} \mathrm{C}$. Approximately $0.2-0.4 \mathrm{ml}$ emulsion was then injected intradermally at the rat's base of tail under general anaesthesia using diethyl ether. This amount the collagen-CFA emulsion injected was adjusted to the body weight of the rat on day 1 of arthritis induction. The optimum concentration of emulsion to be injected was previously determined through a pilot study conducted in International Medical University [23].

\subsection{Preparation and Administration of Treatments}

Curcumin ( $>95 \%$ ) was purchased from Natural Remedies, India, $\geq 99 \%$ crystalline Acetylsalicylic acid from Sigma Aldrich, USA. Curcumin was prepared in a standard vehicle of $0.5-0.7 \mathrm{ml} 100 \%$ olive oil. The amount administered was at concentrations of $500 \mathrm{mg} / \mathrm{kg}$, $1000 \mathrm{mg} / \mathrm{kg}, 2000 \mathrm{mg} / \mathrm{kg}$ based on the weight of the rat at day 25 for arthritic groups. This dosage was selected based on previous established works [5]. As curcumin was delivered by oral gavage using a gavage tube, direct entry into the gastrointestinal surface was 
ensured. Moreover, the gavage was done on empty stomach before the actual feeding, hence ensuring optimum absorption without much wastage. Body weight is measured every 4 days and the dosage is changed accordingly for each rat during the treatment period. Appropriate quantities of curcumin were added to falcon tubes containing olive oil and thoroughly mixed using a sonicator ensuring both oil particles have combined to an even mixture. The compound was stored wrapped in aluminum foil, as it is light sensitive. Treatment was administered as oral supplementation daily using syringes without needle from day 25 to day 38 for 3 arthritic groups at the aforementioned concentrations respectively. Aspirin was similarly dissolved in water at a concentration of $3 \mathrm{mg} / \mathrm{ml}$. Each rat received a dosage $25 \mathrm{mg} / \mathrm{kg}$ aspirin based on the weight at day 25 for arthritic group daily for 14 days. Body weight is measured every 4 days and the dosage is changed accordingly for each rat during the treatment period. Combination treatments were also administered to three arthritic groups; $500 \mathrm{mg} / \mathrm{kg}$ curcumin and $25 \mathrm{mg} / \mathrm{kg}$ aspirin; $1000 \mathrm{mg} / \mathrm{kg}$ curcumin and $25 \mathrm{mg} / \mathrm{kg}$ aspirin; $2000 \mathrm{mg} / \mathrm{kg}$ curcumin and $25 \mathrm{mg} / \mathrm{kg}$ aspirin from day 25 to 38 . One noninduced group received only $0.5 \mathrm{ml}$ olive oil from day 25 to 38 , and one arthritic group received $25 \mathrm{mg} / \mathrm{kg}$ aspirin, which were used as negative and positive control group.

\subsection{Histological Examination}

The knee joints of the rats were collected on day 39 of experimental cycle and were fixed in $10 \%$ formalin, decalcified, trimmed, and embedded. After sectioning, the slides were stained using haematoxylin and eosin staining. The slides were scored by a qualified pathologist based on these criteria; oedema, cellular infiltration, joint space, synovial hyperplasia, fibrosis and erosion (see Table 1). This grading system was developed by a previous study [24].

\subsection{Immunohistochemistry}

The degree of inflammation in the rats was assessed using NF-KB levels in the knee joints. Rabbit polyclonal antibody to NF-KB p65 were purchased from ABCAM, UK. It was utilized to assess and grade the level of NF-KB in the knee joints through immunohistochemistry Table 1.

\subsection{Cytokines (TNF- $\alpha$ and IL-1 $\beta$ ) and Gluthathione Peroxidase Levels}

On the last day of the experimental cycle (day 39), blood samples were collected from the animals. After anesthetization with ether, approximately 3-5 ml of blood was obtained from each rat through cardiac puncture, resulting in its death. Tumour Necrosis Factor Alpha (TNF- $\alpha$ ) and Interleukin - 1 Beta (IL-1 $\beta$ ) levels were quantified using the rat TNF-alpha Platinum ELISA kit (eBioscience, USA) and rat IL-1 beta Tissue Culture ELISA Ready-SETGo!@ kit (Cayman Chemical, USA) respectively. Gluthathione Peroxidase assay kit (Cayman Chemical, USA) was used to quantify the Gluthathione Peroxidase (GPx) levels. All the procedures were followed according to the respective manufacturer's protocol.

\subsection{Statistical Analysis}

All data was analysed using SPSS v.18 (SPSS Inc, Chicago, IL, USA). Mann Whitney U test for nonparametric data was used to analyse the arthritic scores and NF-kB expression. Data from ELISA was analysed using one-way ANOVA followed by Tukey's test. For all the tests, $p=0.05$ was considered to be significant. 


\section{RESULTS AND DISCUSSION}

\subsection{Histopathological Analysis}

Fig. 1 The histological change was scored in the knee of normal and CIA rats. A) Normal, wide joint space (red arrow) and presence of healthy cartilage (blue arrow) is seen in the non-induced + vehicle group (H \&E, 200x). B) Synovial hyperplasia (blue arrow), characteristic finding in RA is seen in arthritis + vehicle group (H\&E, 200x). C) Synovial hyperplasia (blue arrow) seeping into the joint space is seen in this arthritis $+500 \mathrm{mg} / \mathrm{kg}$ curcumin group (H\&E, 200x). D) Low level of inflammatory cells (blue arrow) and granulation tissue is seen in this arthritis $+25 \mathrm{mg} / \mathrm{kg}$ aspirin indicative of tissue healing (H\&E, 200x). E) Presence of fresh cartilage proliferation (blue arrow) is found in this arthritis $+500 \mathrm{mg} / \mathrm{kg}$ curcumin $+25 \mathrm{mg} / \mathrm{kg}$ aspirin group (H\&E, 200x). F) A healthy looking joint is shown with no signs of inflammation in the arthritis $+2000 \mathrm{mg} / \mathrm{kg}$ curcumin $+25 \mathrm{mg} / \mathrm{kg}$ aspirin group (H\&E, 100x).

One day following the induction of CIA, the physical activity level of the rats decreased. On day 7 after induction, the swelling of the knee joint started and reached its peak on day 21. The rats started to limp or drag both its hind paws while moving by day 21 . On histological examination of the knee joint, the non-induced group (vehicle) exhibited no signs of inflammatory changes. However, the arthritis (vehicle) and arthritis $+500 \mathrm{mg} / \mathrm{kg}$ curcumin group exhibited all signs of inflammation (oedema, inflammatory cell infiltration, joint space narrowing, snynovial hyperplasia, fibrosis and erosion). Similar findings were found in arthritis (vehicle) group $(p>0.05)$. Interestingly, arthritis $+1000 \mathrm{mg} / \mathrm{kg}$ curcumin, arthritis + $2000 \mathrm{mg} / \mathrm{kg}$ curcumin and arthritis $+25 \mathrm{mg} / \mathrm{kg}$ aspirin all exhibited reduced inflammatory features and signs of healing $(p<0.01)$. Combination treatment groups which are arthritis + $500 \mathrm{mg} / \mathrm{kg}$ curcumin $+25 \mathrm{mg} / \mathrm{kg}$ aspirin, arthritis $+1000 \mathrm{mg} / \mathrm{kg}$ curcumin $+25 \mathrm{mg} / \mathrm{kg}$ aspirin and arthritis $+2000 \mathrm{mg} / \mathrm{kg}$ curcumin $+25 \mathrm{mg} / \mathrm{kg}$ aspirin group showed reduced inflammation and healing when compared to arthritis (vehicle) group $(p<0.05)$. When curcumin alone treated groups $(500 \mathrm{mg} / \mathrm{kg}, 1000 \mathrm{mg} / \mathrm{kg}, 2000 \mathrm{mg} / \mathrm{kg}$ ) and combination treatment groups compared with arthritis $+25 \mathrm{mg} / \mathrm{kg}$ aspirin group, there were no significant difference found in terms of inflammatory features $(p>0.05)$ on histology examination.

\subsection{NF-KB Immunohistochemistry}

Fig. 2 immunohistochemistry for NF-KB p65 antibody was performed on the knee joints, which is stained brown on the tissue sections. A) A scattered expression of NF-kB expression is seen in the non-induced (vehicle) group (IHC, 200x). B) An extensive expression of NF-KB is seen in the arthritis (vehicle) group (IHC, 200x) (blue arrows) C) Arthritis $+1000 \mathrm{mg} / \mathrm{kg}$ curcumin groups exhibits a moderate level of NF-kB expression (IHC,200x) (blue arrows) D) Low level of expression is seen in arthritis $+2000 \mathrm{mg} / \mathrm{kg}$ curcumin group (IHC, 200x). E) \& F) Mild expression of NF-kB is seen in both arthritis +25 $\mathrm{mg} / \mathrm{kg}$ aspirin and arthritis $+2000 \mathrm{mg} / \mathrm{kg}$ curcumin $+25 \mathrm{mg} / \mathrm{kg}$ aspirin group (IHC, 200x). 
A

C

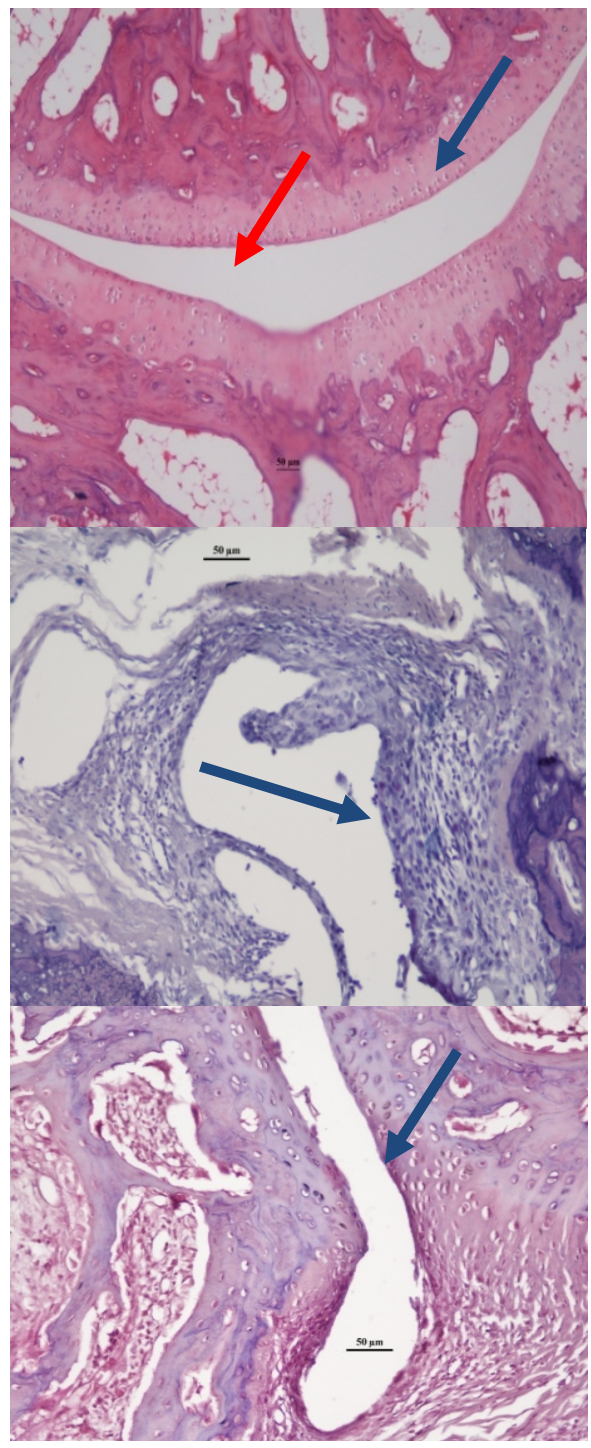

B

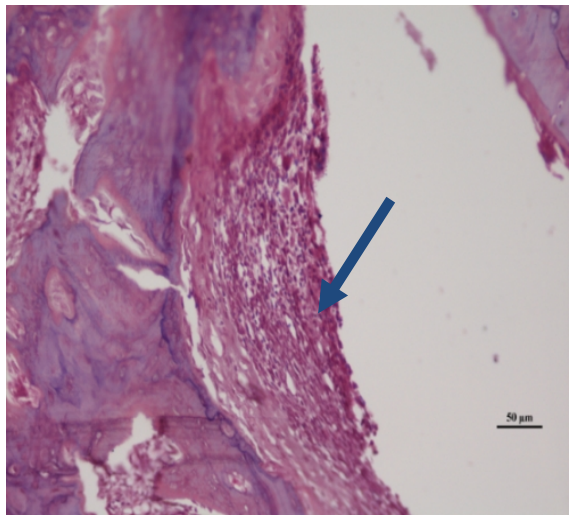

D

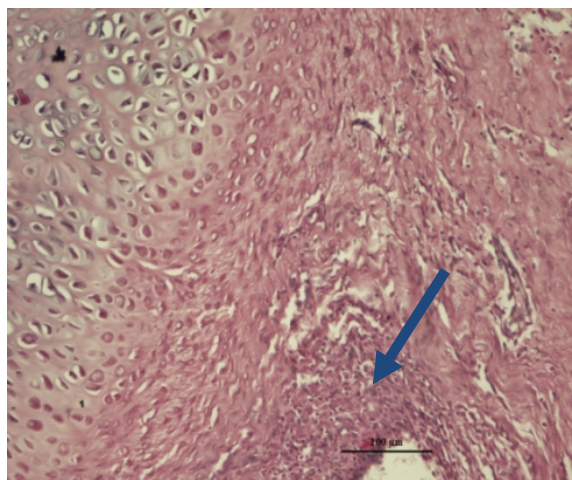

$\mathbf{F}$

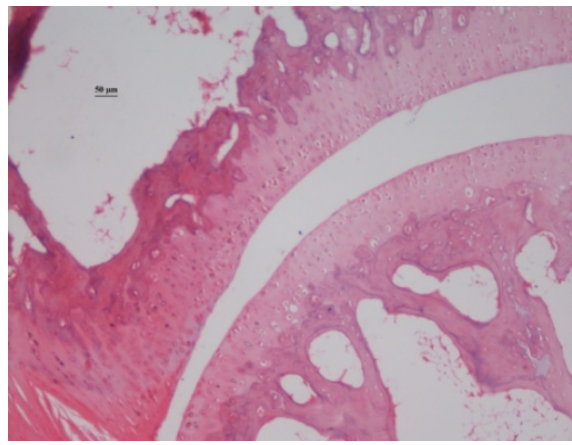

Fig. 1. The histological change was scored in the knee of normal and CIA rats. A) Normal, wide joint space (red arrow) and presence of healthy cartilage (blue arrow) is seen in the non-induced + vehicle group (H \&E, 200x). B) Synovial hyperplasia (blue arrow), characteristic finding in RA is seen in arthritis + vehicle group (H\&E, 200x). C) Synovial hyperplasia (blue arrow) seeping into the joint space is seen in this arthritis $+500 \mathrm{mg} / \mathrm{kg}$ curcumin group (H\&E, 200x). D) Low level of inflammatory cells (blue arrow) and granulation tissue is seen in this arthritis $+25 \mathrm{mg} / \mathrm{kg}$ aspirin indicative of tissue healing (H\&E, 200x). E) Presence of fresh cartilage proliferation (blue arrow) is found in this arthritis $+500 \mathrm{mg} / \mathrm{kg}$ curcumin $+25 \mathrm{mg} / \mathrm{kg}$ aspirin group (H\&E, 200x). F) A healthy looking joint is shown with no signs of inflammation in the arthritis +2000 $\mathrm{mg} / \mathrm{kg}$ curcumin $+25 \mathrm{mg} / \mathrm{kg}$ aspirin group (H\&E, 100x) 


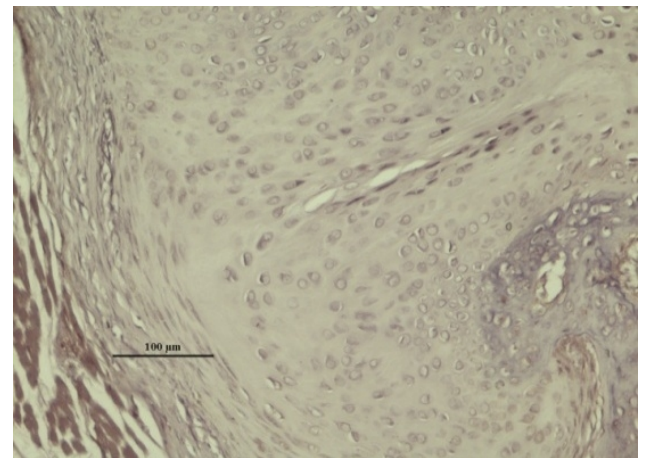

A

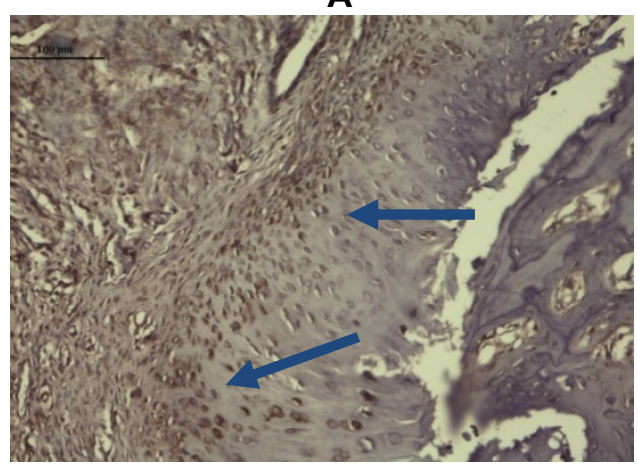

C

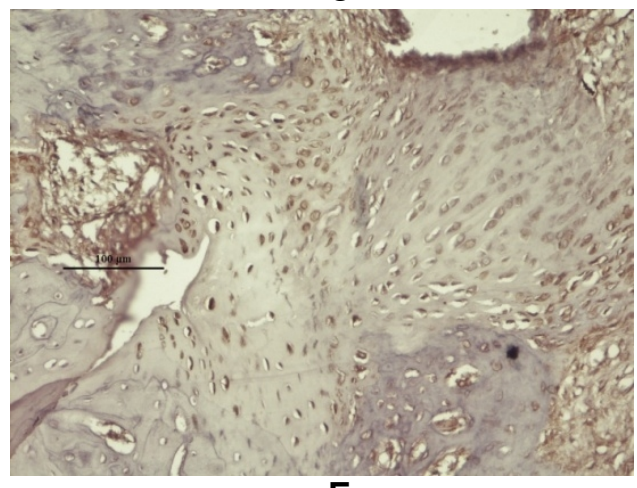

E

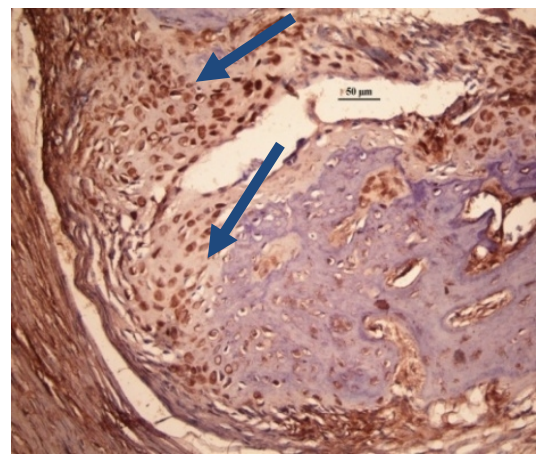

B

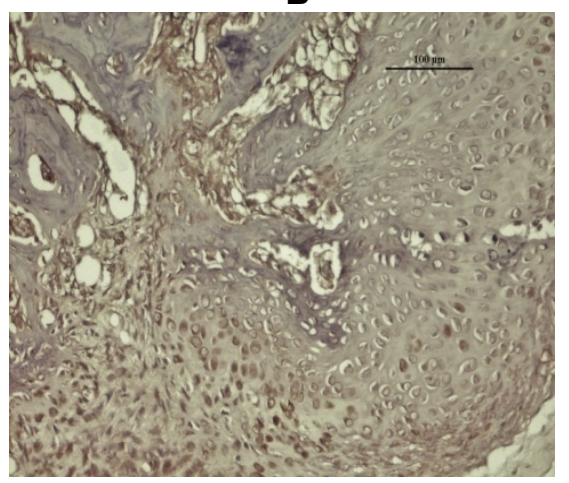

D

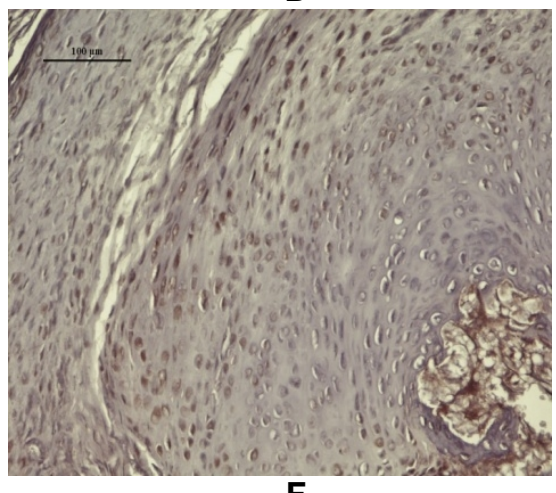

$\mathbf{F}$

Fig. 2. Immunohistochemistry for NF-KB p65 antibody was performed on the knee joints, which is stained brown on the tissue sections. A) A scattered expression of

NF-KB expression is seen in the non-induced ( vehicle) group (IHC, 200x). B) An extensive expression of NF-KB is seen in the arthritis (vehicle) group (IHC, 200x) (blue arrows) C) Arthritis $+1000 \mathrm{mg} / \mathrm{kg}$ curcumin groups exhibits a moderate level of NF-kB expression (IHC,200x) (blue arrows) D) Low level of expression is seen in arthritis + $2000 \mathrm{mg} / \mathrm{kg}$ curcumin group (IHC, 200x). E) \& F) Mild expression of NF-kB is seen in both arthritis $+25 \mathrm{mg} / \mathrm{kg}$ aspirin and arthritis $+2000 \mathrm{mg} / \mathrm{kg}$ curcumin $+25 \mathrm{mg} / \mathrm{kg}$ aspirin group (IHC, 200x).

As seen in Fig. 2, the NF-KB expression in the arthritis (vehicle) group was significantly higher than the non-induced (vehicle) group $(p<0.01)$. Significant reduction in NF-KB expression was observed in arthritis $+25 \mathrm{mg} / \mathrm{kg}$ aspirin $(p<0.01)$, arthritis $+1000 \mathrm{mg} / \mathrm{kg}$ 
curcumin $(p<0.01)$ and arthritis $+2000 \mathrm{mg} / \mathrm{kg}$ curcumin $(p<0.01)$ groups when compared with arthritis (vehicle) group. Significant reduction of NF-kB was found in all the combination treatment groups when compared to the arthritis (vehicle) group $(p<0.01)$. Comparison were also made between arthritis $+25 \mathrm{mg} / \mathrm{kg}$ aspirin and all the combination treatment groups, which revealed good correlation $(p<0.01)$ except in arthritis $+500 \mathrm{mg} / \mathrm{kg}$ curcumin +25 $\mathrm{mg} / \mathrm{kg}$ aspirin group $(p<0.05)$.

\subsection{TNF- $\alpha$ and IL-1 $\beta$ Levels}

In comparison with non-induced (vehicle) groups, TNF- $\alpha$ level was significantly higher in arthritis (vehicle) group $(p=0.05)$. This level continued to decrease until the level was almost similar in arthritis $+2000 \mathrm{mg} / \mathrm{kg}$ curcumin to the level in the non-induced (vehicle) group. Interestingly, the TNF- $\alpha$ levels in the arthritis $+500 \mathrm{mg} / \mathrm{kg}$ curcumin $+25 \mathrm{mg} / \mathrm{kg}$ aspirin and arthritis $+1000 \mathrm{mg} / \mathrm{kg}$ curcumin $+25 \mathrm{mg} / \mathrm{kg}$ aspirin were higher than arthritis and $25 \mathrm{mg} / \mathrm{kg}$ aspirin group $(p=0.05)$. However, the levels were similar between arthritis $+2000 \mathrm{mg} / \mathrm{kg}$ curcumin $+25 \mathrm{mg} . / \mathrm{kg}$ aspirin and arthritis $+25 \mathrm{mg} / \mathrm{kg}$ aspirin group, with no significant difference

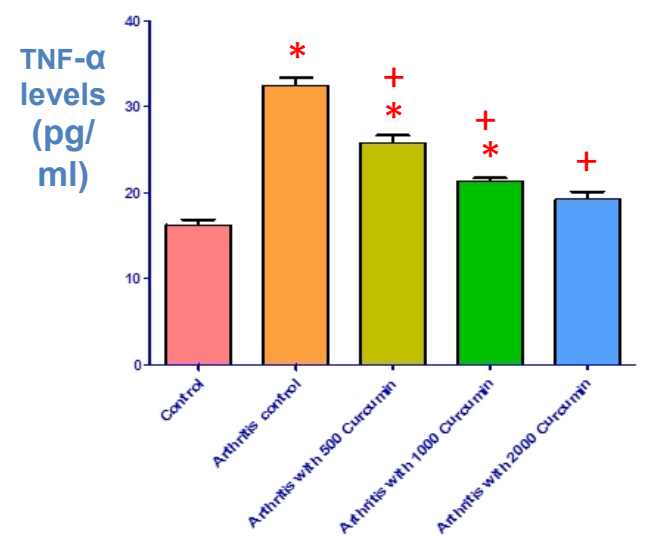

A

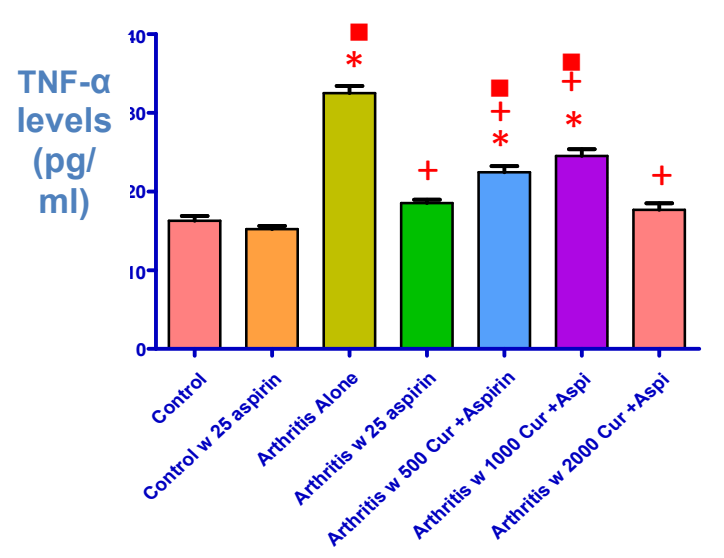

C

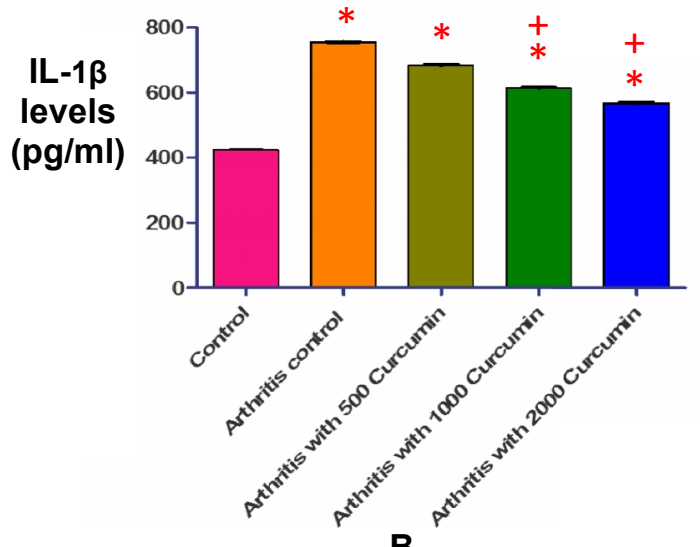

B

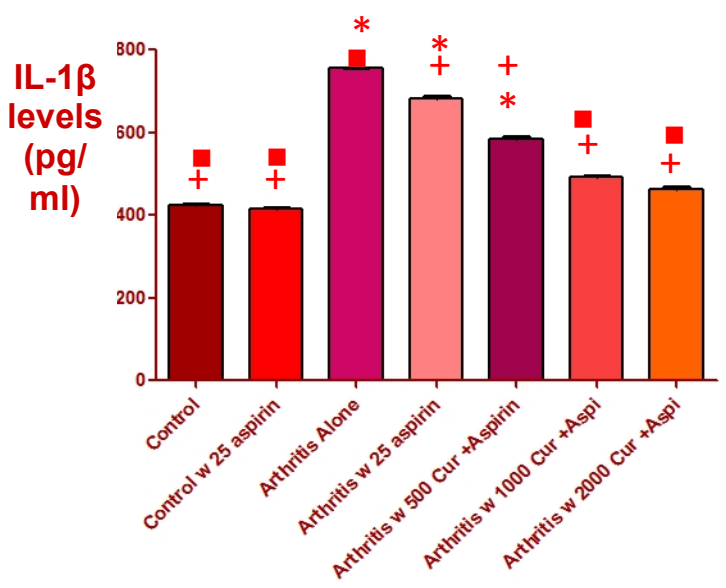

D

Fig. 3. TNF- $\alpha$ and IL-1 $\beta$ Levels

Significance: * $p=0.05$ Non-induced vs other groups; $+p=0.05$ Arthritis alone Vs other groups; $p=0.05$ Arthritis aspirin Vs other groups 
A very similar pattern was seen in term of IL-1 $\beta$ expression as well. The arthritis (vehicle) group expressed significantly higher levels of IL-1 $\beta$ compared to non-induced (vehicle) group $(p=0.05)$. However, only significant reduction of IL-1 $\beta$ levels were only seen in arthritis + $1000 \mathrm{mg} / \mathrm{kg}$ curcumin and arthritis $+2000 \mathrm{mg} / \mathrm{kg}$ curcumin groups $(p=0.05)$. In the combination treatment groups, arthritis $+1000 \mathrm{mg} / \mathrm{kg}$ curcumin $+25 \mathrm{mg} / \mathrm{kg}$ aspirin and arthritis $+2000 \mathrm{mg} / \mathrm{kg}$ curcumin $+25 \mathrm{mg} / \mathrm{kg}$ aspirin groups expressed significantly lower levels of IL- $1 \beta$ levels compared to the arthritis $+25 \mathrm{mg} / \mathrm{kg}$ aspirin group $(p=0.05)$.

\subsection{Gluthathione Peroxidase Activity Level}

Gluthathione peroxidase levels was significantly higher in the non-induced (vehicle) group in comparison to all other groups $(p=0.05)$. Nonetheless, arthritis $+500 \mathrm{mg} / \mathrm{kg}$ curcumin, arthritis $+1000 \mathrm{mg} / \mathrm{kg}$ curcumin and arthritis $+2000 \mathrm{mg} / \mathrm{kg}$ curcumin showed significant increase in GPx level when compared to the arthritis (vehicle) group $(p=0.05)$. Similarly, all the combination treatments groups showed significant increase when compared to the same group $(p=0.05)$. Only arthritis $+2000 \mathrm{mg} / \mathrm{kg}$ curcumin $+25 \mathrm{mg} / \mathrm{kg}$ aspirin group showed significant increase in GPx level when compared to arthritis $+25 \mathrm{mg} / \mathrm{kg}$ aspirin group $(p=0.05)$.

This study was done to observe the effect of curcumin in arthritis and also its relationship with the function of NF-KB. Curcumin has been widely used as a therapeutic agent in traditional medicine for several centuries. Scientific studies on role of curcumin in health related conditions are fairly new in the research world. Much of the research in curcumin has been focused in areas like, cancer, wound healing, malaria and just to name a few [25].

Effect of curcumin in arthritis has not been studied much except for a few research works which have highlighted the role of curcumin in arthritis. Mun et al. demonstrated that oral administration of curcumin ameliorates type II collagen-induced arthritis in mice. They also reported that it inhibits the production of matrix metalloproteinase-1 and matrix mettaloproteinase III production in CIA is mediated through the inhibition of protein kinase $\mathrm{C} \delta$ (PKCס) and the JNK/c-Jun signaling pathway [26].

Rheumatoid arthritis involves several cytokines in its pathogenesis. However, TNF- $\alpha$ is considered to be at the apex of of cytokine cascade that lead to pathological changes in RA. Development of anti TNF- $\alpha$ therapy has been successful in disease remission to a certain extent $[14,15]$. Interleukin- $1 \beta$ is another main cytokines that contribute to the disease progression and therapy against this cytokine has been proven effective $[15,16]$. Oxidative damage by free oxygen radical has been associated in the pathobiology of rheumatoid arthritis. Glutathione peroxidase dependent mechanism is one of the pathway erythrocyte utilized to scavenge free oxygen radical, in order to minimize the extent of damage to tissue [17].

On another study conducted by Okamoto et al., similar finding was reported, through inhibition of Interleukin-17 (IL-17) [27]. Recently, a clinical trial was carried out by Chandran et al. on the efficacy and safety of curcumin on active rheumatoid arthritis patients, which was then proven to be more effective than diclofenac sodium, an established antiinflammatory. No adverse events was reported [28]. Hence, it is justifiable to study its effect in management of rheumatoid arthritis [29]. 


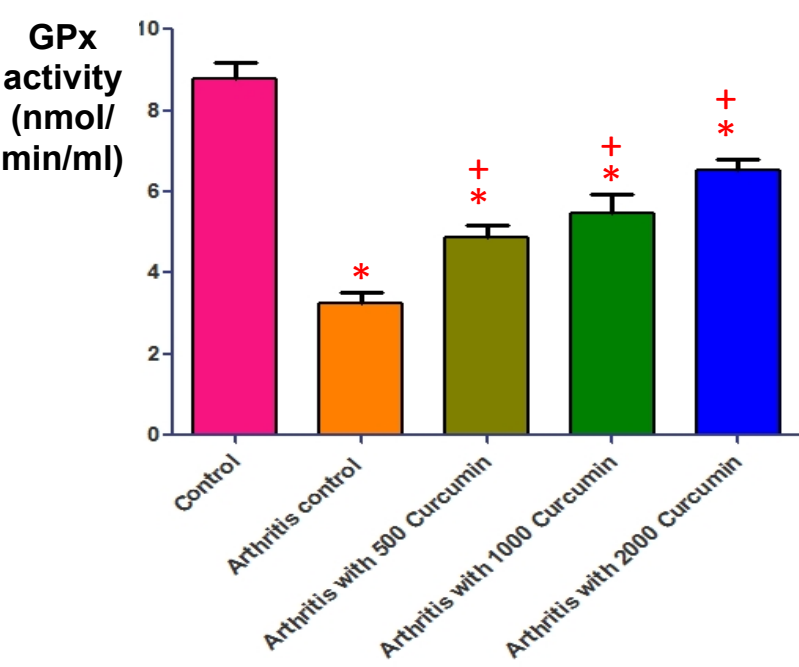

A

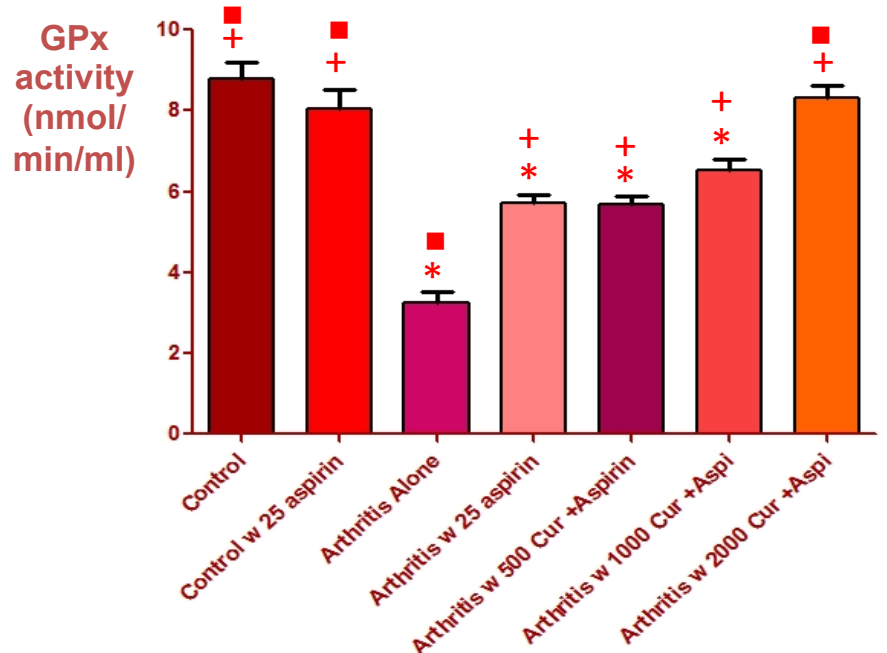

B

Fig. 4. Gluthathione Peroxidase Activity Level

Significance: * $p=0.05$ Non-induced vs other groups; $+p=0.05$ Arthritis alone Vs other groups; $v p=0.05$ Arthritis aspirin Vs other groups 
The role of NF-KB in arthritis is an established one. It has proinflammatory properties and is expected to increase the level of inflammation and hence, would be expected in high concentration when there is arthritis, whether the arthritis is an active form of disease or whether there is a certain amount of healing [30]. Therefore, the level of NF-kB would vary depending on the tissues in the joints in normal, inflammatory, healing, and healed tissue.

Nuclear factor kappa-B in arthritis has been studied extensively, some of which have been referred to in this study. Yamasaki et al. proved that NF-KB is highly expressed in synovial tissue from rheumatoid arthritis patients [31]. Inhibitor of nuclear factor kappa $B$ kinase (IKK $\beta$ ) activation, causes the NF-KB translocation into the nucleus to initiate inflammatory response. This was demonstrated in Lewis rats by Tak et al [32]. To further clarify the role of NF-KB, Tsuchiya et al., proved that inhibition of translocation of NF-KB to the nucleus resulted in reduction of cytokines production that is involved in rheumatoid arthritis $[33,34]$.

In the histopathology study, there were no morphological changes in the non-induced + vehicle group. However, in the arthritis (vehicle) and arthritis $+500 \mathrm{mg} / \mathrm{kg}$ curcumin, there was extensive damage to the joint including oedema, inflammatory cell infiltrates, joint space narrowing, synovial hyperplasia, fibrosis and bone erosion. This difference was significant $(p<0.05)$ when compared to the control group.

Observation on the arthritis $+1000 \mathrm{mg} / \mathrm{kg}$ curcumin, arthritis $+2000 \mathrm{mg} / \mathrm{kg}$ curcumin and all combination treatment groups and arthritis $+25 \mathrm{mg} / \mathrm{kg}$ aspirin showed a significant reduction in pathology and also areas of healing as suggested by the presence of granulation tissue which is seen as proliferation of small blood vessels and fibroblast. Our histopathological changes due to curcumin at higher doses treatment after induction of arthritis were comparable to studies done. $[26,35]$.

Non-induced group (vehicle) showed nil or scattered expression of NF-KB. Over expression of NF-KB was seen in arthritis (vehicle) and arthritis $+500 \mathrm{mg} / \mathrm{kg}$ curcumin. Arthritis +1000 $\mathrm{mg} / \mathrm{kg}$ curcumin, arthritis $+2000 \mathrm{mg} / \mathrm{kg}$ curcumin, arthritis $+25 \mathrm{mg} / \mathrm{kg}$ aspirin and all combination treatment groups showed low to moderate expression. Combination group of $1000 \mathrm{mg} / \mathrm{kg}$ curcumin and $2000 \mathrm{mg} / \mathrm{kg}$ curcumin together $25 \mathrm{mg} / \mathrm{kg}$ aspirin, showed significant result when compared to aspirin treated arthritic group $(p<0.05)$.

In short, inflammatory response was lower at higher doses of curcumin, and it was even better when given together with aspirin. Several studies have documented inhibition of NFKB by curcumin, but only in cell line by Singh et al. [7].

Both TNF- $\alpha$ and IL-1 $\beta$ levels were found to be increased in the arthritis groups and comparatively decreased in all the treated groups with more prominent reduction observed as curcumin dosages increased, along with aspirin. It was even more reduced in combination treatment groups.

Glutathione peroxidase was found to be decreased in the arthritis (vehicle) and arthritis + $500 \mathrm{mg} / \mathrm{kg}$ curcumin groups and showed increasing levels in the healing groups and this were comparable to negative control group. Combination group again showed higher levels of GPx than aspirin treated arthritic group. These reduction of TNF- $\alpha$ and IL-1 $\beta$ and increase in GPx level in amelioration of CIA due to treatment were consistent with several other studies [36,37]. 
Based on these findings, curcumin given after arthritis in high doses, shows effects of healing and this results were comparable to positive control group, which is the arthritic group treated with $25 \mathrm{mg} / \mathrm{kg}$ aspirin. Curcumin given in combination with aspirin, showed better reduction in pathology in arthritic group compared to positive control group, especially with higher doses of curcumin.

\section{CONCLUSION}

In this study, curcumin has been found to have a therapeutic effect in the treatment of CIA in DA rats, however only at higher doses. The action of curcumin has an inverse proportional relationship with NF-KB expression as observed in other studies. It also shows that combination treatment of aspirin and curcumin is beneficial in CIA, which need further research including clinical trials. This can bring about major changed in the treatment of rheumatoid arthritis with fewer side effects that is currently through the use of natural compounds like curcumin.

For future study, this therapeutic effect of curcumin on the expression of NF-KB in CIA may be reaffirmed by real time polymerase chain reaction (q-PCR) method. In the next level of animal study, curcumin can be compared to a primary anti-rheumatic drug, such as methotrexate to further assess its therapeutic efficacy.

\section{CONSENT}

Consent was not applicable in this work as this was an animal study.

\section{ETHICAL APPROVAL}

All authors hereby declare that "Principles of laboratory animal care" were followed. All experiments have been examined and approved by the research and ethics committee of International Medical University, Malaysia.

\section{ACKNOWLEDGEMENTS}

This project was funded by a research grant (Grant no. BS112010-95000, 2012-13) from the International Medical University, Kuala Lumpur, Malaysia.

\section{COMPETING INTERESTS}

Authors have declared that no competing interests exist.

\section{REFERENCES}

1. Ammon HP, Wahl MA. Pharmacology of Curcuma longa. Planta Med. 1991;57(1):1-7.

2. Sharma RA, Gescher AJ, Steward WP. Curcumin: the story so far. European journal of cancer. 2005;41(13):1955-68.

3. Flynn DL, Rafferty MF, Boctor AM. Inhibition of 5-hydroxy-eicosatetraenoic acid (5HETE) formation in intact human neutrophils by naturally-occurring diarylheptanoids: inhibitory activities of curcuminoids and yakuchinones. Prostaglandins, Leukotrienes and Medicine. 1986;22(3):357-60. 
4. Gupta B, Ghosh B. Curcuma longa inhibits TNF- $\alpha$ induced expression of adhesion molecules on human umbilical vein endothelial cells. International Journal of Immunopharmacology. 1999;21(11):745-57.

5. Xu YX, Pindolia KR, Janakiraman N, Noth CJ, Chapman RA, Gautam SC. Curcumin, a compound with anti-inflammatory and anti-oxidant properties, down-regulates chemokine expression in bone marrow stromal cells. Experimental hematology. 1997;25(5):413-22.

6. Okada K, Wangpoengtrakul C, Tanaka T, Toyokuni S, Uchida K, Osawa T. Curcumin and especially tetrahydrocurcumin ameliorate oxidative stress-induced renal injury in mice. Journal of Nutrition. 2001;131(8):2090-5.

7. Singh S, Aggarwal BB. Activation of transcription factor NF-kappa B is suppressed by curcumin (diferuloylmethane). The Journal of Biological Chemistry. 1995;270(42):24995-5000.

8. Ghosh S, May MJ, Kopp EB. NF-kappa B and Rel proteins: evolutionarily conserved mediators of immune responses. Annual Review of Immunology. 1998;16:225-60.

9. Kumar A, Takada Y, Boriek AM, Aggarwal BB. Nuclear factor-kappaB: its role in health and disease. Journal of Molecular Medicine. 2004;82(7):434-48.

10. Huber LC, Distler O, Tarner I, Gay RE, Gay S, Pap T. Synovial fibroblasts: key players in rheumatoid arthritis. Rheumatology (Oxford). 2006;45(6):669-75.

11. Makarov SS. NF-kappaB in rheumatoid arthritis: a pivotal regulator of inflammation, hyperplasia, and tissue destruction. Arthritis Research. 2001;3(4):200-6.

12. Rothschild BM, Turner KR, DeLuca MA. Symmetrical erosive peripheral polyarthritis in the Late Archaic Period of Alabama. Science. 1988;241(4872):1498-501.

13. Woolf AD, Pfleger B. Burden of major musculoskeletal conditions. Bulletin of the World Health Organization. 2003;81(9):646-56.

14. Khurana R, Berney SM. Clinical aspects of rheumatoid arthritis. Pathophysiology. 2005;12(3):153-65.

15. Alamanos $Y$, Voulgari $P V$, Drosos AA. Incidence and prevalence of rheumatoid arthritis, based on the 1987 American College of Rheumatology criteria: a systematic review. Seminars in arthritis and rheumatism. 2006;36(3):182-8.

16. Gabriel SE, Michaud K. Epidemiological studies in incidence, prevalence, mortality, and comorbidity of the rheumatic diseases. Arthritis Research \& Therapy. 2009;11(3):229.

17. MacGregor AJ, Snieder H, Rigby AS, Koskenvuo M, Kaprino J, Aho K, Silman AJ. Characterizing the quantitative genetic contribution to rheumatoid arthritis using data from twins. Arthritis \& Rheumatism. 2000;43(1):30-7.

18. Silman AJ, Newman J, MacGregor AJ. Cigarette smoking increases the risk of rheumatoid arthritis. Results from a nationwide study of disease-discordant twins. Arthritis \& Rheumatism. 1996;39(5):732-5.

19. Klareskog L, Padyukov L, Rönnelid J, Alfredsson L. Genes, environment and immunity in the development of rheumatoid arthritis. Current Opinion in Immunology. 2006;18(6):650-5.

20. Smolen JS, Aletaha D, Koeller M, Weisman MH, Emery P. New therapies for treatment of rheumatoid arthritis. Lancet. 2007;370(9602):1861-74.

21. Firestein GS. NF-kappaB: Holy Grail for rheumatoid arthritis? Arthritis \& Rheumatism. 2004;50(8):2381-86.

22. Brand DD, Latham KA, Rosloniec EF. Collagen-induced arthritis. Nature protocols. 2007;2(5):1269-75. 
23. Tudave D, Radhakrishnan A, Chakravarthi S, Haleagrahara N. Modulation of Creactive protein and tumour necrosis factor-alpha in collagen-induced arthritis in Dark Agouti rats: impact of collagen concentration on severity of arthritis. Inflammation Research. 2011;60(10):897-907.

24. Lee KH, Chen YS, Judson JP, Chakravarthi S, Sim YM, Er HM. The effect of water extracts of Euphorbia hirta on cartilage degeneration in arthritic rats. Malaysian Journal of Pathology. 2008;30(2):95-102.

25. Tan Jackie, Nagaraja HS, Srikumar Chakravarthi. Antioxidant effects of Etlingera elatior flower extract against lead acetate - induced perturbations in free radical scavenging enzymes and lipid peroxidation in rats. BMC Research Notes. 2011;(4)67:1-8.

26. Mun SH, Kim HS, Kim JW, Ko NY, Kim do K, Lee BY, et al. Oral administration of curcumin suppresses production of matrix metalloproteinase ( MMP ) -1 and MMP-3 to Ameliorate Collagen-Induced Arthritis : Inhibition of the PKC $/$ JNK / c-Jun Pathway. Journal of Pharmacological Sciences. 2009;111(1):13-21.

27. Okamoto Y, Tanaka M, Fukui T, Masuzawa T. Inhibition of interleukin 17 production by curcumin in mice with collagen-induced arthritis. Biomedical Research. 2011;22(3):299-304.

28. Chandran B, Goel A. A Randomized, Pilot Study to Assess the Efficacy and Safety of Curcumin in Patients with Active Rheumatoid Arthritis. Phytotherapy research. 2012;26(11):1719-25.

29. Xuzhu G, Komai-Koma M, Leung BP, Howe HS, McSharry C, McInnes IB, et al. Resveratrol modulates murine collagen-induced arthritis by inhibiting Th17 and B-cell function. Annals of the Rheumatic Diseases. 2012;71(1):129-35.

30. Nagaraja HS, Ravinder Jassal, Srikumar Chakravarthi, Thanikachalam P, Nagarajah Lee, Anupama BK. Apigenin effects on Cyclosporine-A Induced Changes in Lipid Hydroperoxides and Total Antioxidants in Sprague-Dawley Rats. Journal of Chinese Clinical Medicine. 2009;4(1):26-31.

31. Yamasaki S, Kawakami A, Nakashima T, Nakamura H, Kamachi M, Honda S, et al. Importance of NF-kappaB in rheumatoid synovial tissues: in situ NF-kappaB expression and In vitro study using cultured synovial cells. Annals of the Rheumatic Diseases. 2001;60(7):678-84.

32. Tak P, Gerlag D, Aupperle K, Van De Geest DA, Overbeek M, Bennett BL, et al. Inhibitor of nuclear factor $\mathrm{kB}$ kinase $\beta$ is a key regulator of synovial inflammation. Arthritis \& Rheumatism. 2001;44(8):1897-907.

33. Tsuchiya A, Imai K, Asamitsu K, Waguri-nagaya Y, Otsuka T, Okamoto T. Inhibition of inflammatory cytokine production from rheumatoid synovial fibroblasts by a novel IKB kinase inhibitor. Journal of Pharmacology and Experimental Therapeutics. 2010;333(1):236-43.

34. Nagaraja Haleagrahara, Tan Jackie, Srikumar Chakravarthi, Anupama Bangra Kulur. Protective effect of alpha-lipoic acid against lead acetate-induced oxidative stress in the bone marrow of rats. International Journal of Pharmacology. 2011;1-11.

35. Nagaraja HS, Srikumar Chakravarthi, Lee N, Tan Mun Yee. Protective effect of Nacetylcysteine on cyclosporine a induced changes in lipid hydroperoxide levels and renal dysfunction in rats. Archives of Medical Science. 2009;5(1):16-22.

36. Ganesan K, Tiwari M, Balachandran C, Manohar BM, Puvanakrishnan R. Estrogen and testosterone attenuate extracellular matrix loss in collagen-induced arthritis in rats. Calcified Tissue International. 2008;83(5):354-64. 
37. Wu H, Maron R, Tukpah A. Mucosal anti-CD3 monoclonal antibody attenuates collagen-induced arthritis that is associated with induction of LAP+ regulatory $T$ cells and is enhanced by administration of an emulsome-based Th2-skewing adjuvant. Journal of Immunology. 2010;185(6):3401-7.

(c) 2014 Somasundaram et al.; This is an Open Access article distributed under the terms of the Creative Commons Attribution License (http://creativecommons.org/licenses/by/3.0), which permits unrestricted use, distribution, and reproduction in any medium, provided the original work is properly cited.

Peer-review history:

The peer review history for this paper can be accessed here: http://www.sciencedomain.org/review-history. php?iid=455\&id=12\&aid=3928 